\title{
PROTECTION OF TRADITIONAL HANDICRAFTS: THE LITHUANIAN CASE
}

\author{
Lina Pareigienė, Erika Ribašauskienė \\ Lithuanian Institute of Agrarian Economics, Lithuania \\ lina.pareigiene@laei.lt; erika.ribasauskiene@laei.lt
}

\begin{abstract}
The preservation and nurturance of national heritage products, which are inherent to particular localities, are very significant for the economic and social vitality, and sustainable development of a country. National handicrafts are a means of maintaining national identity, originality, and distinction in a constantly changing world. For a long time Lithuania was an agrarian country, so its cultural heritage and handicrafts are closely related to the rural environment, culture, traditions, and materials. Nowadays this heritage is a very important source of alternative employment opportunities. In 2007 Lithuania enacted the Law of National Heritage Products; in 2008 and 2011 Programmes for the Protection of National Heritage Products, their Market and Development of Handicrafts were approved. The goal was to provide governmental support to create favourable conditions for the creation, realisation and popularisation of national heritage products. The aim of this paper is to evaluate the situation with traditional handicraft protection in Lithuania within the Programme implementation framework and to submit proposals for better implementation. The analysis shows that not all Programme goals were achieved: those for which municipalities were responsible were implemented better than those implemented by governmental institutions. A presumption could be made that the top-down approach is only partially suitable for the Programme implementation. The partners from the 'bottom' (associations, local activity groups) should be involved in the implementation of the Programme to reach better results.
\end{abstract}

Key words: cultural heritage, national heritage protection, traditional handicrafts, Lithuania, new social movements.

\section{Introduction}

2018 was officially launched by the European Union as the European Year of Cultural Heritage. The aim is to raise awareness of Europe's cultural heritage, which has the power to bring communities together and to build a shared understanding of the uniqueness of the place we live in. Cultural heritage is the basis of every nation's identity, helping to keep the consciousness of the nation as distinctive amidst the community of nations. Preservation of national cultural heritage, formed interactively with landscape, traditions and knowledge, stimulates sustainable development (Kniūkšta, 2014). Some authors argue that culture is a crucial element in sustainable development, as it forms peoples' identities, cosmologies and epistemic frameworks, determining how the environment is viewed, understood and lived in, including social and economic systems. Culture shapes how humans act in the surrounding world (Nurse, 2006; Hawkes, 2001).

Cultural heritage is divided into the tangible and the intangible. According to the UNESCO Convention for the Safeguarding of the Intangible Cultural Heritage 'intangible cultural heritage means the practices, representations, expressions, knowledge, skills - as well as the instruments, objects, artefacts and cultural spaces associated therewith that communities, groups and individuals recognise as part of their cultural heritage' (UNESCO, 2003). Cultural heritage encompasses traditions, performing arts, social practices, rituals, festivals, knowledge and practices concerning nature and the universe and national handicrafts. Manufacturing of traditional heritage products is especially important for rural dwellers as alternative economic activity when the importance of agriculture in the employment structure of rural population is declining.

The preservation of national handicrafts is the topic of this article. To protect traditional handicrafts means to implement measures which ensure the viability of heritage through ensuring continuous practice, maintenance of the process of heritage production, and transmission of knowledge and skills through education for future generations. Until 2007 the laws protecting national handicrafts were incorporated in common governmental programmes as cultural protection laws. Legal protection was episodic, directed towards implementation of projects, separate measures and initiatives, and the different institutions took part in protection processes: there was no integrated view.

In 2007 the Parliament of the Republic of Lithuania, prompted by non-governmental associations and organisations, announced the Law of National Heritage Products (the Law), which was a strong top-down attempt to preserve traditional handicrafts as one part of the cultural heritage. The Law ensured governmental protection, allowing protection and dissemination of accumulated experience of national handicrafts. The principles of governmental maintenance were created. The Law defined national heritage products as the traditional handicraft products of craftsmen. The Law determined the principles of handicraft product classification and certification process, and specified favourable conditions for traditional craftsmen to create, realise, and popularise products of national heritage (The Republic of Lithuania, 2007).

Certification ensured that products were made from traditional materials, by traditional methods, protecting 
unique features, composition, and colour of wares. The system of certification enabled the systematisation of handicrafts and products of national heritage, marked with a specially-created logo. There are 72 certified, historically developed traditional handicrafts, and more than 2,700 certified national heritage products produced by around 600 certified craftsmen.

In 2008 the government of the Republic of Lithuania approved 'The Programme for Protection of National Heritage Products, their Market and Development of Handicrafts for 2008 - 2015' (the Programme), it was suspended in 2011 and a new, advanced Programme for 2012 - 2020 was approved. In this Programme a wide spectrum of governmental institutions were and are taking part: the Ministry of Agriculture of the Republic of Lithuania, Ministry of Culture, Ministry of Economy, Ministry of Environment, Lithuanian State Department of Tourism under the Ministry of Economy, and municipalities (self-government institutions). The meaning of traditional handicraft protection is multifunctional, which is why, for the preservation and adaptation to contemporary requirements, an integrated approach concerning implementation of protection measures was necessary. The multiplicity of selected cultural heritage protection measures was revealed in the Programme for Protection of National Heritage Products, their Market and Development of Handicrafts for 2012 - 2020 (further Programme). It was planned to operate in the economic dimension of sustainable development (job creation, income generation), the social dimension (development of a training system), and the environmental dimension (presentation, promotion and the use of cultural resources) (The Government of the Republic of Lithuania, 2011).

The situation and development possibilities of traditional handicrafts were analysed by $\mathrm{V}$. Atkočiūnienè, A. Aleksandravičius and D. Albrektaitė et al., (2008b), V. Rudzkienè and R. Skrodenytė (2012). E. Ribašauskienè and D. Šumylè (2016) investigated the activity of traditional handicraft centres, G. Parafinavičè and I. Krikštaponytè (2010) analysed the realities and prospects of traditional craftsmen education and skills training. A. Aleksandravičius et al. $(2008,2009,2012)$ researched endogenous and exogenous factors influencing the development of handicrafts and the role of traditional handicrafts in rural sustainable development. J. Ramanauskienè and Z. Vagonis (2010) investigated the benefits of interaction between the rural tourism and handicrafts. B. Žuromskaite (2010) aimed to discover the role of traditional handicrafts in promoting cultural tourism. No research was done to investigate the results of the Programme implementation.

The aim of this paper is to evaluate the situation with the traditional handicraft protection in Lithuania within the Programme implementation framework and to submit proposals for better implementation. The tasks of the paper are: 1) to analyse the development of national heritage protection inspirations in Lithuania; 2) to examine the extent of craftsmen involvement in the Programme, identifying the main challenges.

\section{Materials and Methods}

Analysis of scientific literature, national documents, and discourse analysis were used to disclose the theme. To achieve the aim of the paper, the quantitative method of structured questionnaire was applied.

The intermediate results of Programme implementation were evaluated by comparing planned indicators with the achieved results.

Three information sources were used to gather information about the implementation of the Programme: governmental organisations, municipalities, and craftsmen. The data from governmental organisations and self-governmental institutions were chosen to supplement the answers of craftsmen and for better explanation.

To evaluate the intermediate results of the Programme implementation, the structured questionnaire was conducted in September-November of 2016 for two groups - certified craftsmen and municipal agents. 567 certified producers of national crafts were asked to fill in a questionnaire on an internet platform. 233 answers were received: according to statistics this ensures the representativeness of research with a confidence level of 95 per cent and a 5 per cent margin of error. The questionnaire was designed to investigate such themes as demographic characteristics of surveyed respondents, duration of activity and its aspects, and the use of government support measures. The research data were analysed using an Excel package. 53.6 per cent of respondents were dwellers of rural areas and small cities, and 46.4 per cent were town craftsmen. 61.8 per cent have been creating national heritage products for more than 10 years, 23.2 per cent for $6-10$ years, and 13.7 per cent for 5 years and less. 65.2 per cent of respondents were women. The most frequent activities were knitting, weaving, pottery, carving, baking of bread, food preparation, and production of sweets. The majority of respondents were $40-59$ years old, 18.0 per cent -60 years and older, 15.9 per cent $29-$ 39 years old and the smallest number -2.6 per cent, were younger than 29 .

The questionnaire was sent by an e-mail to all municipalities of Lithuania, 31 responses were received, and it composed 51.7 per cent of the general set. According to statistics with a confidence level of 95 per cent, the margin of error was 10 per cent. They were asked to indicate what measures they implement to improve the preservation of traditional craftsmen. 
For the governmental organisations participating in the Programme implementation, official letters were sent asking them to contribute their input.

\section{Results and Discussion}

\section{Tendencies of the cultural heritage protection}

The preservation of cultural heritage has a long tradition in Lithuania. It was very important in the period when Lithuania was under the Soviet regime and started around the 1960s. The goals of the ethnocultural movement were to explore the country and regions, to preserve and clean monuments, to collect folklore and old songs, to organise ethnographic expeditions, folk groups and folk clubs, and to keep national traditions. Acting in secret, as the Soviet government inhibited such activity, a complex network of circles of friends, private and public spaces, hid under the legal shelter of official organisations. Conflict was directed towards the existing government, and activists sought to dissociate from the reality of Soviet society by establishing an alternative worldview, promoting alternative social norms of behaviour and community values (Ramonaitè \& Kukulskyte, 2014). The members of movement were persecuted, punished and sanctioned, but an alternative community was formed and connected by a common identity. With the help of community members, meeting places and festivals were hidden, while a whole communication system existed. Because of the political situation, persecuted activists chose those forms of collaboration which reflected the networking principles of new social movements. According to scientific literature, this ethnocultural movement could be seen as a new social movement as it satisfies the main features and elements of new social movements scientists distinguish: conflictual interaction with opponents, networks of informal exchanges between individuals and/or organisations, and collective identity (Diani, 2002). The reason new social movements arise is the human will to resist the state and state interference in the lives of private people (Žukaite, 2016). The nature of new social movements is cultural and oriented towards a struggle for quality of life. The goal is to reconstruct values, personal identities and cultural symbols, contributing to the emergence of alternative lifestyles (Tovey, 2002). In contrast, the so-called old social movements were directed towards reducing material inequalities, while new social movements are guided by non-material considerations, concerning the achievement of symbolic goals, and the defence of symbolic resources (Woods, 2003).

After Lithuania regained independence in 1990, joining the EU in 2004, political, economic, and social circumstances changed. While activities and networking of social movements transformed, the tendency to preserve national cultural heritage in grassroots ways still persists as an addition flow for governmental or top-down preservation of cultural heritage. In the face of globalisation, consuming mass culture products, Europeanisation, and the threat of convergence - the willingness to protect our nation's individuality and its identity intensified. Non-governmental associations, non-profit seeking organisations (Lithuanian Folk Artists' Association, Lithuanian Association of Ethnic Culture, and others) were established with the purpose of protecting ethnic culture and national heritage, and to unite national craftsmen. They sought common purposes: to protect national cultural heritage, handicrafts, identity, to keep traditions, improve the quality of life by suggesting better quality of handicraft products, which are not mass cultured ones. Those bottom-up initiators induced national government to pay more attention to national heritage and especially to protection of traditional heritage products, handicrafts and craftsmen. With pressure from them, the special Laws in 2007, 2008, and 2011 were accepted. The bottom-up approach in the preservation field was essential in the period of the Soviet Union and lasted as an important inspiration for cultural protection in later times.

\section{Results of Programme implementation}

For the evaluation of craftsmen involvement in the Programme, four indicators, corresponding to objectives of the Programme, were measured:

- the craftsmen's participation in government supported measures (implementation of the responsibility of government institutions);

- the creation of work places by craftsmen (implementation of the responsibility of government institutions);

- the improvement of craftsmen's qualifications (implementation of the responsibility of government institutions);

- the influence of government support on the improvement of national heritage product image (implementation of the responsibility of government institutions and municipalities).

One of the objectives of the Programme was 'To develop the state support which will promote the preservation, creation and realisation of national heritage products'. The data of the craftsmen survey showed that on average 30.5 per cent of respondents used state support under the 'Programme for the Protection of National Heritage Products, their Market and Crafts Development for 2012 - 2020' each year to develop their craft activity. 85.9 per cent of respondents used the support for participation in exhibitions, fairs and festivals, 74.6 per cent purchased equipment or adapted premises for the activity, 67.6 per cent used support funds for product certification, and 59.1 per 
cent for the publishing and organisation of educational events. The Programme predicted that 60 per cent of craftsmen would participate and use the government support measures. Achievement of the planned goal required an ambitious annual increase of at least 10 percentage points of craftsmen participating in state support measures. The results of the survey also showed that the main reasons for not using the state support was lack of their own resources, and the lack of information about support measures. This could be explained by the Programme's implementation topdown principles when the highest-level institutions are responsible for the support supply. The top-down implementation principle of the Programme does not assure optimal collaboration between the support provider and recipient. Government institutions are too distant from the craftsmen and top-level information needs to be easily accessible by craftsmen. It is especially important bearing in mind that the majority of craftsmen live in rural areas and small towns, and are middle aged or older. No less important reasons for the non-use of governmental support are the complicated requirements and limited access for urban craftsmen, because a part of the measure is financed by the Rural Development Programme 2014-2020, the purpose of which is to support rural dwellers.

An objective to ensure the adoption of ethnic cultural values and the continuity of traditional handicrafts through the creation of new working places was stated in the Programme. The survey data disclosed that only 13.8 per cent of respondents, using governmental support, created workplaces for themselves or family members. Half of those who created workplaces created part-time workplaces for themselves, one third of craftsmen created a full-time workplace for themselves, one fifth created a part-time workplace for a family member. Only 5.2 per cent of respondents created a full-time workplace.

One fifth of respondents indicated that support had no effect on creation of workplaces, and none were created. Such survey results allow assuming that in 2020 the planned target will not be achieved. The Programme forecasts that 100 workplaces would be created in 2020 as a result of implementing support measures. According to the survey results, from 2012 to 2016 only one third of the planned number of workplaces were created during the period. Here it could be stated that top-down implementation of the desired goal to create workplaces did not give the predicted results, and the approach was not vindicated.

By implementing the third objective of the Programme 'To develop and coordinate the traditional craft training system', it was expected that in 2020 the share of traditional craftsmen whose qualification level in the handicraft sphere will be evaluated as increased, following the implementation of the Programme measures, would reach 80.0 per cent. Governmental institutions are responsible for the implementation of this objective. Only 22.0 per cent of craftsmen pointed out that their level of qualification has risen due to the implementation of the Programme measures. This number discloses that a danger arises that the purpose of the criterion will not be achieved if no changes are made. The main causes of such a low result are the inadequate actions of the institutions involved in the implementation of the Programme by developing and coordinating the traditional craft education system. Methodologies necessary for qualification development were insufficiently developed, the network for the development of competences for national heritage product developers was not created, and the management, marketing, and entrepreneurship training was not organised. A large proportion of traditional craftsmen are middle-aged and elderly, and their entrepreneurship and ability to work under today's business conditions are scant. On the other hand, the production of national heritage products requires a lot of time and labour costs; it is not a very lucrative economic activity, so it is unattractive for young people. In traditional craft technology training the transmission system is sluggish, so some crafts are on the brink of extinction. The proposal would be to dispense the implementation functions to the more flexible, adoptable bottom-up approach, when the lower institutions often are more capable to organise actual training in their regions in response to the requirements of craftsmen.

The fourth objective of the Programme was to 'Form the attractive image of national heritage products in the country and abroad' and the Programme stipulates that by 2020 , the average image of national heritage products will grow by 10 per cent a year among consumers. One of the most important measures of forming the image of national heritage products is certification of such products by the Ministry of Agriculture and the provision of a national heritage label. 88.0 per cent of craftsmen used a certification logo to mark their production: 60.5 per cent always, 27.5 per cent sometimes. The craftsmen survey results showed that 26.6 per cent of respondents believe that because of the use of the national heritage label for more than 20.0 per cent of consumers the image of craftsmen production has improved, correspondingly 24.8 per cent indicated that image has improved for $5-$ 14.0 per cent of consumers and 24.0 per cent indicated that image of national heritage products has improved for $15-20$ per cent of consumers. It should also be noted that municipalities contribute significantly to the image formation of the national heritage products. The survey of municipal administrators showed that, in most municipalities, the promotion of national heritage products and traditional services 
was organised in the form of exhibitions, traditional festivals and fairs: 75.0 per cent of respondents participating in the municipalities' survey organised such events more than 8 times during the period of 2008 - 2016. 51.6 per cent of the representatives of the municipal administrations indicated that more than once a year they place information about national heritage on the web site of the municipality, 32.3 per cent - that seminars were organised at least once a year in the municipality's territory. About a half of municipalities provided craftsmen with franchise to trade, to obtain business licenses. This shows that the formation of national heritage product image is positive and that the analysed objective of the Programme's implementation for 2020 is being achieved.

The results disclosed that from the viewpoint of craftsmen not all indicators of the Programme will be achieved. One of the reasons is the top-down approach of the implementation principles. The Convention for the Safeguarding of the Intangible Cultural Heritage states that every state must take the necessary measures to preserve elements of cultural heritage and to involve as wide a range of participants in preservation as possible (UNESCO, 2003). Today's situation and the received evaluation show that the input to the Programme only of the governmental organisations is insufficient. It is necessary to include a wider spectrum of actors in the Programme implementation. Measures prepared and used in the top-down approach should be supplemented by bottom-up support, which must be included in the Programme. The results disclosed that the implementation level was higher of those objectives of the Programme where the topdown and bottom-up approach were combined, i.e. where protection measures included a wider range of supporting groups: government and municipal authorities. The bottom-up principle is characterised by cooperation, civic participation, local democracy. It manifests itself through direct representation, shown by the direct identification of needs and expectations, the involvement of local organisations in the formulation and implementation of policy decisions, and the achievement of policy goals and objectives through local agents (Atkočiūnienè, 2008).

Therefore, in the future, in order to ensure the most effective protection of cultural heritage and handicrafts and a more fluent implementation of the Programme, participation and cooperation must be assured, as well as synergy between different agents: local action groups, local communities, craft centres, associations, municipalities and governmental institutions. J. Blake (2009) emphasises the necessity to generate a statecommunity approach, or in other words bottom-up and top-down partnership, with the government role as supportive in the sense of finance and expertise. A new approach to the preservation of cultural heritage should be discussed and the functions must be distributed among different levels of organisations.

In this paper, the formal legally-established protection of traditional handicrafts was analysed and this is the most frequent evaluation trend. Alongside the formal preservation of national heritage, which could be called the top-down approach, a bottom-up approach prevails, arising from grassroots activities. Historically bottom-up initiatives are inherent to Lithuania and have features of a new social movement. This approach could be explained by the fact that not all initiatives are formed from the top, but arise from the grassroots. The dimension of new social movements could be an additional feature explaining the results of the Programme. It could suggest one explanation why the formal support is so little used, as another dimension of cultural, handicraft protection exists. At least 8 associations, non-profit organisations operating for the protection of cultural heritage can be identified; they unite craftsmen and artists concerned about their activities and organise exhibitions, festivals, and fairs, develop publishing activity, and organise seminars and conferences. The phenomenon of a new social movement could be explained by the fact that formal side, the top-down approach to the preservation of national heritage does not affect all craftsmen: some act independently, not wanting to participate in formal structures, or participating only a little. A number of craftsmen are not certified, as it is their lifestyle choice to make some crafts in their leisure time - nor do they seek national support; they do not join formal networks or structures, but they participate in the preservation of cultural heritage in other different ways, through initiatives taken by associations. New social movements dissociate from institutional systems and are responses to life politicisation, when policy does not protect some interests. New social movements act like a protest against modernity (Gorlach, Lostak, \& Mooney, 2008). The role of new social movements is shaping society. The intention to maintain cultural tradition reflects a collective (nationalist, folk) transformative identity construction within civil society that forms islands in the sea of public liberation. This dissociation from traditional channels could be the basis for growth of new social movements (Gorlach, Lostak, \& Mooney, 2008). The role and purpose of the movements in protecting national heritage and traditional handicraft preservation should be examined in future, broader research.

\section{Conclusions}

The preservation of national cultural heritage has a long tradition in Lithuania. The grassroots movement of heritage protection during the Soviet period could be defined as one of the flows. Alongside governmental 
protection the grassroots movement remains important following Lithuania's regaining independence. This ethnocultural movement acted according to the principles of new social movements and was the bottom-up initiative which prompted government to preserve traditional national handicrafts by law.

The analysis of the intermediate results of the Programme implementation showed a potential danger that not all objectives of the Programme will achieve planned results. It is especially important with regard to measures which were implemented by governmental institutions: that is the use of support measures, the creation of workplaces for craftsmen and the increase of craftsmen's qualification level. The improvement of the image of national heritage products produced by craftsmen will achieve planned goals because the objective of this Programme will be implemented by municipalities, which are in closer relationship with craftsmen than are governmental institutions.

The results of the craftsmen survey disclosed that the handicraft preservation implementation levels were higher where the approaches of top-down and bottom-up were combined, i.e. where protection measures included a wider range of supporting groups, for example, government and municipal authorities. Therefore, in order to ensure the most effective protection of cultural heritage and handicrafts, participation and cooperation, as well as synergy between participants like local action groups, local communities, craft centres, associations, government, and municipalities must be assured. The activity and influence of the movement towards cultural protection from the bottom-up level, which acts under the principles and ideology of new social movements, should be investigated more extensively.

\section{References}

1. Aleksandravičius, A., \& Klupšas, F. (2009). Tradicinių amatų išsaugojimo ir jų plètros svarba kaimo darniam vystymuisi (The Importance of Preserve and Development of Traditional Handicrafts for Sustainable Rural Development). Vadybos mokslas ir studijos - kaimo verslu ir ju infrastruktūros plètrai, Nr. 19(4), 6-13. (in Lithuanian).

2. Aleksandravičius, A., Atkočiūnienè, V., \& Raupelienè, A. (2008). Tautinio paveldo produktų išsaugojimo ir plètros svarba kaimo darniai plètrai (The Importance of Preserve and Production Development of Products of National Heritage for Sustainable Rural Development). Ekonomika ir vadyba: aktualijos ir perspektyvos, Nr. 2(11), 228-233. (in Lithuanian).

3. Aleksandravičius, A., \& Zastarskytè, E. (2012). Tradicinių amatų vystymą kaimo vietovèse ịtakojantys endogeniniai ir egzogeniniai aplinkos veiksniai (The Endogenous and Exogenous Factors Influencing the Development of Traditional Handicrafts in Rural Areas). The 5th International Academic-practical Conference: Examples of Good Practices in Strengthening the Competitiveness of the Lithuanian Rural Areas, 25 September 2012 (pp. 23-29). Akademija: Aleksandras Stulginskis University. (in Lithuanian).

4. Atkočiūnienè, V. (2008). Kaimo vietovės pokyčių valdymas pagal principą "iš apačios ị viršų" (The Expression of the Principle "bottom up" Organizing, Taking and Realizing the Strategical Disocions of Change Management of Rural Areas). Ekonomika ir vadyba: aktualijos ir perspektyvos, Nr. 2 (11), 6-14. (in Lithuanian).

5. Atkočiūnienè, V., Aleksandravičius, A., \& Albrektaitè, D. (2008). Tradicinių amatų situacija Lietuvoje ir jų plètros galimybès (The Situation and Development Possibilities of Traditional Handicrafts in Lithuania). Vadybos mokslas ir studijos - kaimo verslu ir ju infrastruktūros plètrai, Nr. 12(1), 24-32. (in Lithuanian).

6. Blake, J. (2009). UNESCO's 2003 convention on intangible cultural heritage: the implications of community involvement in "safeguarding”. In L. Smith, \& N. Akagava, N. (Eds.), Intangible Cultural Heritage (pp. 45-73). London: Routledge.

7. Diani, M. (1992). The Concept of Social Movement. The Sociological Review, Nr. 40(1), 1-25. DOI: 10.1111/j.1467-954X.1992.tb02943.x.

8. Gorlach, K., Lostak, M., \& Mooney, P.H. (2008). Agriculture, Communities and New Social Movements: East European Realities in the Process of Restructuring. Journal of rural Studies, Nr. 24, 161-171. DOI: 10.1016/j.jrurstud.2007.12.003.

9. Hawkes, J. (2001). The Fourth Pillar of Sustainability: Culture's Essential Role in Public Planning. Melbourne: Common Ground Publishing.

10. Kniūkšta, B. (2014). Ekonominè lokalizacija kaip priemonè darniam vystymuisi igyvendinti: teorinis požiūris (Economic Localization as a Tool for Sustainable Development: a Theoretical Approach). In Sustainable Development: Theory and Practice (pp. 67-89). Vilnius: Vilniaus universitetas. (in Lithuanian).

11. Nurse, K. (2006). Culture as the Fourth Pillar of Sustainable Development. In: Small states: economic review and basic statistics (pp. 32-48), London: Commonwealth Secretariat. 
12. Ramonaitè, A., \& Kukulskytė, R. (2014). Etnokultūrinis judejjimas sovietmečiu: nematoma alternatyva sistemai? (The Ethno-cultural Movement in Soviet Lithuania: Invisible Alternative to the Regime). Lietuvos etnologija: socialinés antropologijos ir etnologijos studijos, Nr. 14(23), 161-181. (in Lithuanian).

13. Parafinavičè, G., \& Krištaponytè, I. (2010). Tradicinių amatininkų mokymo ir meistriškumo kèlimo realijos bei perspektyvos (Realities and Prospects of Traditional Artisans Education and Skills Training). Ekonomika ir vadyba: akrualijos ir perspektyvos, Nr. 3 (19), 49-58. (in Lithuanian).

14. Ramanauskienè, J., \& Vagonis, Z. (2010). Kaimo turizmo ir amatų sąveikos nauda, skatinimo galimybės (Interaction Between Rural Tourism and Crafts: Benefit and Incentive Possibilities), Vagos. Nr. 86 (39), 20-27. (in Lithuanian).

15. Ribašauskienè, E. \& Šumyle, D. (2016). The Role of Traditional Craft Centres in Safeguarding Cultural Heritage. Management theory and Studies for Rural Business and Infrastructure Development, Vol. 38, Nr. 4, 412-424. DOI: 10.15544/mts.2016.33.

16. Rudzkienè, V., \& Skrodenytè, R. (2012). National heritage and development of traditional handicraft centres. Societal studies, Nr. 4(4), 1457-1471.

17. Žaromskaitè, B. (2011). Tradicinių ir senųų amatų panaudojimo galimybès, populiarinant kultūrinị turizmą Lietuvoje (Role of Traditional and Old Handicrafts for the Promotion of Cultural Tourism in Lithuania). Kaimo raidos kryptys žinių visuomeneje, Nr. 2, 167-175. (in Lithuanian).

18. The Government of the Republic of Lithuania (2011). Resolution about The Program for Protection of National Heritage Products, their Market and Development of Handicrafts for 2012-2020). December $14 \mathrm{~d}$. Nr. 1475. Retrieved February 2, 2018, from: https://www.e-tar.lt/portal/lt/legalAct/TAR.52B91BE5AFBE (in Lithuanian).

19. The Republic of Lithuania (2007). The Law on National Heritage Products. Nr. X-1207. Retrieved February 3, 2018, from: https://www.e-tar.lt/portal/lt/legalAct/TAR.52B91BE5AFBE. (in Lithuanian).

20. Tovey, H. (2002). Alternative Agricultural Movements and Rural Development Cosmologies. International Journal of the Sociology of Food and Agriculture, Nr. 10(1), 1-11.

21. UNESCO (2003). Convention for the Safeguarding of the Intangible Cultural Heritage, Paris 17, October. Retrieved February 2, 2018, from: http://unesdoc.unesco.org/images/0013/001325/132540e.pdf.

22. Woods, M. (2003). Deconstructing Rural Protest: The Emergence of a New Social Movement. Journal of rural Studies, Nr. 19, 309-325. DOI: 10.1016/S0743-0167(03)00008-1.

23. Žukaitè, G. (2016). Socialinių judejimų sampratos kaita (The Change of Social Movement Concept). Filosofija. Sociologija, T.27. Nr.2, 106-115. (in Lithuanian). 